\title{
THE RESULT OF RESIDENTIAL SEGMENT OF RENEWABLE ENERGY PRODUCTION IN HUNGARY
}

\author{
Balázs KULCSÁR \\ University of Debrecen Faculty of Engineering Institute of Industrial Process Management Department of Basic \\ Technical Studies, Debrecen, Hungary, kulcsarb@eng.unideb.hu
}

\begin{abstract}
The proportion of renewable energy sources must be increased to reduce the energy dependence and energy cost of municipalities, to increase energy security and to consider aspects of the environment. The purpose of this research is to determine how and to what extent small-size household power plants (SSHPP) - which belong to the category of smallest-scale power plants -can contribute to providing the electricity supply with regard to all the Hungarian settlements.
\end{abstract}

Keywords: renewable energy, solar energy, Hungary, self-sufficient settlement, small-size household power plants.

\section{Introduction}

The primary energy consumption of Hungary in 2015 was 999.4 PJ, 420.2 PJ of which came from domestic production and 715.6 PJ was imported (from this latter figure, the 158.3 PJ export has been deducted, and the 21.9 PJ change in the available stock has been added).

The primary domestic energy consumption in 2015 was 999.4 PJ, of which the quantity of energy produced from domestic renewable energy resources and wastes reached $89 \mathrm{PJ}$, while the imported energy also from renewable sources added up to 3.9 PJ. The quantity of primary domestic energy consumption produced exclusively from renewable energy resources, and reduced with the quantity of energy produced from the non-renewable portion of communal wastes, reached 78.5 PJ, and thus the share of renewables and communal waste was $7.9 \%$ of the total energy consumption [1].

\subsection{Small-size household power plants}

Magyar Villamosenergia-ipari Átviteli Rendszerirányító Zrt. (Hungarian Transmission System Operator Company Ltd - MAVIR) distinguishes the following power plant categories with respect to the capacity of the power plants within the Hungarian electrical power system. Basically, power plants under $50 \mathrm{MW}$ are categorized as small power plants, whereas those of $50 \mathrm{MW}$ and above are large power plants. Small power plants with capacities between 0.5 and $50 \mathrm{MW}$, between 0.05 and $0.5 \mathrm{MW}$ and below $0.05 \mathrm{MW}$ are distinguished within the below-50 MW category [2].

Act LXXXVI/2007 on electricity [3] and Gov. Decree 273/2007 (Oct 19) on the enforcement of the Act [4] introduced the term small-size household power plant (SSHPP). Any electricity-generating equipment is categorized as SSHPP if it is connected to a communal low-voltage network or the private or connecting cable network, and the nominal capacity of the power plant does not exceed $50 \mathrm{kVA}$ or the capacity that is available for the user. This approximately fits small power plants with $50 \mathrm{~kW}$ installed capacities at the maximum.

In the 8 years since the SSHPP category was created, its installed national total capacity has been increasing by leaps and bounds. The total capacity at the end of 2008 was only $0.51 \mathrm{MW}$, while by the end of 2015 it exceeded $128 \mathrm{MW}$.

In the SSHPP category, solar cell power plants feature the largest installed capacity, i.e. 127.569 MW, which represents $99.48 \%$ of the power plants belonging to this category. In 2015, it meant a to- 
tal of 15,136 household-scale solar stations of the 15,226 power plants in this power plant category.

This capacity increase is remarkable despite the fact that the price paid for excess production tends to be under the total end-user tariff [5].

\section{Data and methods}

The total quantity of electricity supplied to Hungary's 3155 settlements amounted to $35,760 \mathrm{GWh}$ in 2015 [6], of which 74.709 GWh represented the quantity of electricity produced by small-size household power plants [7]. The settlement-level SSHPP unit and capacity data were made available to us by EON Energiaszolgáltató Kft., ELMÜ-ÉMÁSZ Energiaszolgáltató Zrt. and Délmagyarországi Áramszolgáltató Zrt. (DÉMÁSZ) as universal suppliers operating in the territory of Hungary. The data relating to the territory of ELMÜ-ÉMÁSZ are incomplete, and therefore only the data for 2014-2015 could be used within the period from 2008 to 2015. For this reason, instead of the data of the 15,226 HMKE units installed by the end of 2015 (and representing a combined capacity of $128.863 \mathrm{MW}$ ), settlement-related studies could only be performed on 13,616 power plants with the total capacity of $117.843 \mathrm{MW}$. This figure is associated with 1610 power plants and 11.02 MW capacity less than the nationally published value. The precise, settlement-level electricity production data are treated as a trade secret by the universal suppliers and Magyar Villamosenergia-ipari Átviteli Rendszerirányító Zrt. (MAVIR), and thus have not been made available to us. As a result, the settlement data have been generated by calculations based on the following principles.

As the first step, the available settlement-level capacity data for 2015 were considered, from which the theoretical volume of the electricity generated annually was determined. The calculations were made with the help of the Photovoltaic Geographical Information System operated by the European Commission Joint Research Centre Ispra, Italy [8]. With this system, the calculations were carried out with the use of a theoretical $1 \mathrm{~kW}$ capacity solar cell erected in Pusztavacs, the settlement located at the geological centre of Hungary (Location: 479'44" North, 19³0'11" East, Elevation: $132 \mathrm{~m}$ a.s.l.). In this process, when the annual value of sunshine hours is taken into consideration, the $1 \mathrm{~kW}$ solar cell capacity would produce $1100 \mathrm{kWh}$ electricity annually. This value was considered for the entire territory of the country and the total capacity installed by the end of 2015. In this context, the total SSHPP capacity of $128.863 \mathrm{MW}$ built by the end of 2015 is capable of generating approximately 141.749 GWh electricity on a yearly basis. The capacity of the 13,616 power plants that are available in the settlements is $117.843 \mathrm{MW}$, which can produce $129.627 \mathrm{GWh}$ electricity based on the method described above. The settlement ranking has been made in respect of these data.

\section{The role of small-size household po- wer plants in the electricity supply of the settlements}

In 2015, there small-size household power plants were operating in 1759 of Hungary's 3155 settlements. The altogether 13,616 SSHPP units were run in the 1759 settlements with 117.843 MW total installed capacity [9].

The electricity demand of the 1759 settlements operating SSHPP units was 34,056 GWh in 2015 [5], of which 129.627 GWh is the quantity of electricity that can be generated with small-size household power plants in view of the above-mentioned calculations. This volume of generated electricity can satisfy $0.38 \%$ of the existing electricity demand.

To answer the central question of the study what percentage rate of the electricity demand of the given settlement can be satisfied with the volume of electricity annually produced by the SSHPP category from renewable sources -, it can be stated that settlements with a few, but certainly environmentally conscious inhabitants rank in the top 20 places. The settlement of Bonnya has the best ratio of covering its annual electricity demand from SSHPP units that generate electricity from renewable energy resources, and the resulting value reaches as high as $45 \%$ for the entire settlement. The second place belongs to Selyeb with $38 \%$ and the third goes to Kiszsidány with $31 \%$.

Among the settlements with more than 10,000 inhabitants, Kistarcsa is the first in the list, as this settlement satisfies $2.2 \%$ of its electricity demand from electricity produced by SSHPP units. With this ratio, however, it ranks $286^{\text {th }}$. In this category, Püspökladány is the second, where $1.9 \%$ of the annual electricity demand is covered by small power plants of this category, which places the settlement to $347^{\text {th }}$ in the rank among all the settlements. Hajdúhadház can boast the third place, satisfying $1.6 \%$ of its electricity consumption 
from SSHPP units. Consequently, it is in the $420^{\text {th }}$ place among all the settlements.

Among the settlements with more than 100,000 inhabitants, Debrecen, the second largest city of Hungary tops the rank, as the city covers $0.77 \%$ of its electricity demand from small power plants installed in its area. With this value, it ranks $875^{\text {th }}$ place among all the settlements. Debrecen is followed by Szeged with $0.67 \%$ and in $961^{\text {st }}$ place on the overall list, whereas Pécs is the third with $0.63 \%$ SSHPP production and the 995th place in the comprehensive ranking. (Figure 1.)

\section{Summary}

In summary, it can be ascertained that among Hungarian settlements the quantity of electricity produced in the category of the smallest, smallsize household power plants remains below the nominal capacity of $50 \mathrm{~kW}$ reaching $45 \%$ of the annual electric power demand in settlements with a few hundred inhabitants. In settlements with more than 10,000 inhabitants, this ratio exceeds $2 \%$, however, in the case of Budapest, the largest settlement with 2 million inhabitants it is only $0.09 \%$.

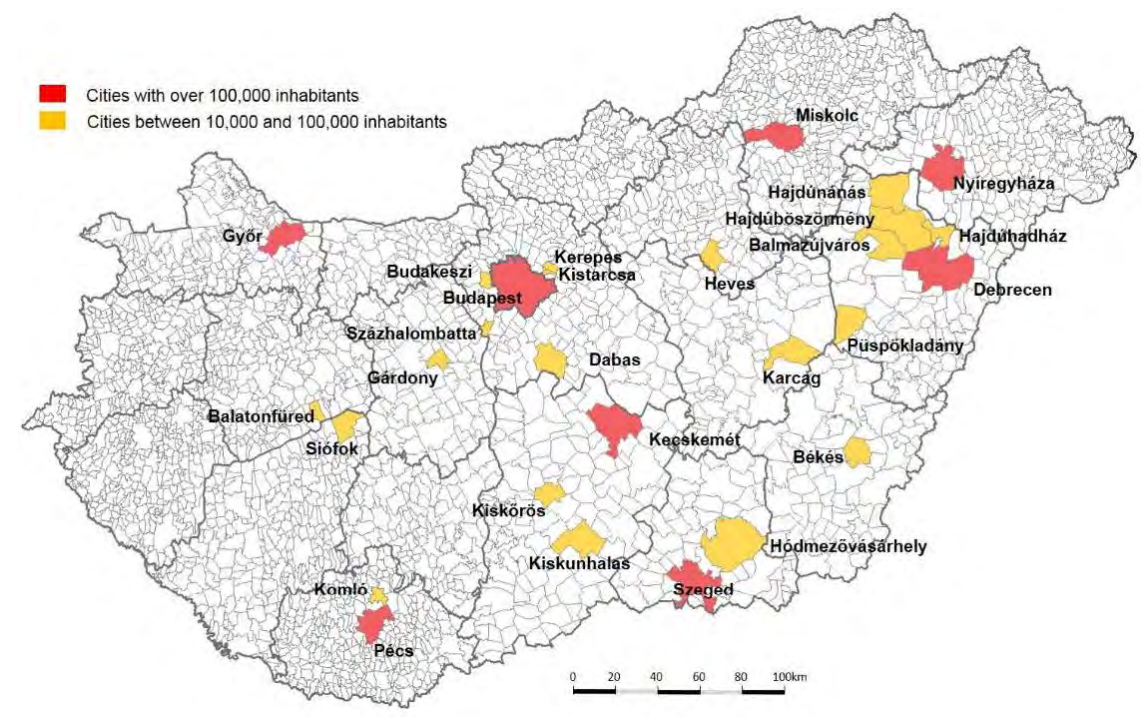

\begin{tabular}{|l|l|l|l|l|l|l|l|l|l|}
\hline \multicolumn{2}{|c|}{$\begin{array}{c}\text { Cities with over 100,000 inhabi- } \\
\text { tants }\end{array}$} & \multicolumn{7}{|c|}{ Cities between 10,000 and 100,000 inhabitants } \\
\hline & SETTLEMENT & $\%$ & & SETTLEMENT & $\%$ & & SETTLEMENT & $\%$ \\
\hline 1 & Debrecen & 0.77 & 1 & Kistarcsa & 2.23 & 11 & Százhalombatta & 1.08 \\
\hline 2 & Szeged & 0.67 & 2 & Püspökladány & 1.93 & 12 & Budakeszi & 1.03 \\
\hline 3 & Pécs & 0.63 & 3 & Hajdúhadház & 1.66 & 13 & Kisújszállás & 0.91 \\
\hline 4 & Ný́regyháza & 0.46 & 4 & Kiskunhalas & 1.41 & 14 & Hajdúnánás & 0.89 \\
\hline 5 & Kecskemét & 0.29 & 5 & Békés & 1.23 & 15 & Balatonfüred & 0.89 \\
\hline 6 & Győr & 0.25 & 6 & Hajdúböszörmény & 1.16 & 16 & Gárdony & 0.85 \\
\hline 7 & Budapest & 0.09 & 7 & Heves & 1.15 & 17 & Dabas & 0.84 \\
\hline 8 & Miskolc & 0.05 & 8 & Siófok & 1.14 & 18 & Kerepes & 0.83 \\
\hline 9 & & & 9 & Kiskőrös & 1.09 & 19 & Balmazújváros & 0.81 \\
\hline 10 & & & 10 & Komló & 1.08 & 20 & Hódmezővásárhely & 0.79 \\
\hline
\end{tabular}

Figure 1. Settlement ranking by the proportion of the electricity produced by small-scale household power plants within the total volume of electric power supplied to the settlement with over 10,000 inhabitants, in 2015 (based on data of KSH, System of regional statistical data, 2015 [9], [5] 
The investment performance of household users, as well as the institutional and corporate segments, has been encouraged only by the savings offered by renewable energy resources, principally solar energy. In the light of these remarkable and promising results, it can be legitimately assumed that the provision of production subsidies to this smallest power plant category would foster the achievement of Hungary's renewable energy targets. Nevertheless, the Renewable Energy Subsidization System (METÁR) introduced on 1 January 2017 still does not support smallsize household power plants, and therefore they remain under the scheme of balance settlement.

The results also seem to contradict the hypothesis that a settlement is incapable of satisfying its own electricity demand from renewable energy resources. The obtained data show that the satisfaction of the electricity demand of a settlement $100 \%$ from local renewable sources - even in the discussed small power plant category - is within reach where small settlements are concerned, and not at all impossible even for small towns.

\section{Acknowledgements}

The work/publication is supported by the EFOP-3.6.116-2016-00022 project. The project is cofinanced by the European Union and the European Social Fund.

\section{References}

[1] MAVIR Hungarian Independent Transmission Operator Company Ltd. (Magyar Villamosenergia-ipari Átviteli Rendszerirányító Zrt.): MAVIR’s statistical data for 2015.

[2] MAVIR Hungarian Independent Transmission Operator Company Ltd. - Data of the Hungarian electricity system 2015. (accessed on: 15.10.2017.) h t t p s:// w w w. m a vir.h u / d o c u ments/10258/154394509/VER-statisztika+2015+-+Final_1.pdf

[3] Act LXXXVI/2007. on electricity

[4] Government Decree 273/2007 (Oct 19) on the enforcement of Act LXXXVI/2007 on electricity.

[5] Hungarian Energy and Public Utility Regulatory Authority - MEKH, (Magyar Energetikai és Közműszabályozási Hivatal, MEKH): Summary of the data relating to small power plants not subject to licensing, including small-size household power plants (2008-2015), (accessed on: 20.07.2017)

http://enhat.mekh.hu/wp-content/uploads/2015/10/osszefoglalo_nem_engedelykoteles_kiseromuvek_adatairol.pdf

[6] Hungarian Central Statistical Office - KSH (Központi Statisztikai Hivatal - KSH): Public Administration Book of Place Names in Hungary, 1 January 2015. Budapest, 2016.

[7] Hungarian Central Statistical Office - KSH (Központi Statisztikai Hivatal - KSH): System of regional statistical data, 2015, Communal service supply, environment based on the data concerning the total quantity of the supplied electricity (MWh) 2015 (settlement), the number of electricity consumers (consumers) 2015 (settlements), and small-size household power plants in the individual settlements.

[8] European Commission Joint Research Centre Ispra, Italy: Photovoltaic Geographical Information System.

http://re.jrc.ec.europa.eu/pvgis/apps4/pvest.php

[9] Hungarian Central Statistical Office - KSH (Központi Statisztikai Hivatal - KSH): System of regional statistical data, 2015, Communal service supply, environment based on the data concerning the total quantity of the supplied electricity (MWh) 2015 (settlement), the number of electricity consumers (consumers) 2015 (settlements), and small-size household power plants in the individual settlements. 